\title{
Video Pembelajaran Berbasis Model Discovery Learning pada Muatan IPS Kelas IV Sekolah Dasar
}

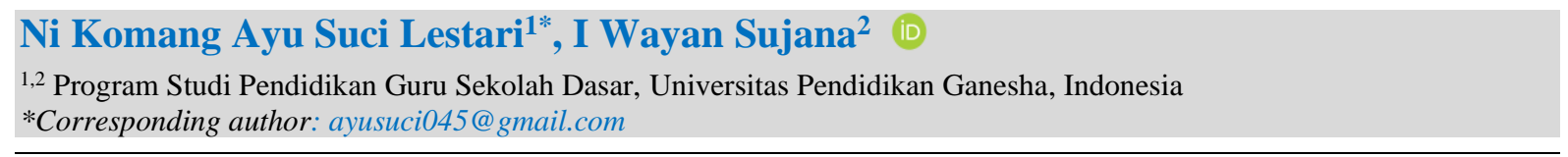

\section{Abstrak}

Keterbatasan guru dalam menemukan media pembelajaran yang tepat pada situasi pembelajaran dalam jaringan merupakan sebuah permasalahan dalam proses pembelajaran. Tujuan penelitian ini untuk menghasilkan produk berupa video pembelajaran berbasis discovery learning yang layak digunakan. Model penelitian yang digunakan adalah model ADDIE (Analyze, Design, Development, Implementation, Evaluation). Metode pengumpulan data yang digunakan yaitu metode wawancara dan kuesioner. Uji rancangan produk dilakukan oleh beberapa ahli dan siswa yang meliputi: (1) ahli isi, (2) ahli desain pembelajaran, (3) ahli media pembelajaran, dan (4) uji coba perorangan yang terdiri dari tiga orang siswa. Metode analisis data yang digunakan adalah analisis data deskriptif kuantitatif dan kualitatif. Berdasarkan data hasil penelitian menunjukkan tingkat persentase kelayakan video pembelajaran menurut ahli isi sebesar $93,75 \%$ dengan kualifikasi sangat baik, tingkat persentase kelayakan video pembelajaran menurut ahli desain pembelajaran sebesar 90,38\% dengan kualifikasi sangat baik, serta tingkat kelayakan video pembelajaran menurut ahli media pembelajaran sebesar $87,5 \%$ dengan kualifikasi baik dan menurut uji coba perorangan tingkat persentase kelayakan video pembelajaran sebesar 91,66\% dengan kualifikasi sangat baik. Berdasarkan hasil penelitian dapat disimpulkan bahwa pengembangan video pembelajaran berbasis model pembelajaran discovery learning layak digunakan dalam proses pembelajaran pada muatan IPS untuk siswa kelas IV di sekolah dasar.

Kata kunci: Video Pembelajaran, Discovery Learning, IPS

\section{Abstract}

The limitation of teachers in finding the right learning media in learning situations in the network is a problem in the learning process. The purpose of this research is to produce a product in the form of a discovery learning-based learning video that is feasible to use. The research model used is the ADDIE model (Analyze, Design, Development, Implementation, Evaluation). Data collection methods used are interviews and questionnaires. The product design test was carried out by several experts and students including (1) content experts, (2) learning design experts, (3) learning media experts, and (4) individual trials consisting of three students. The data analysis method used is quantitative and qualitative descriptive data analysis. Based on the research data, the percentage level of feasibility of learning videos according to content experts is 93,75\% with very good qualifications, the percentage level of feasibility of learning videos according to learning design experts is $90,38 \%$ with very good qualifications, and the feasibility level of learning videos according to media experts learning by $87,5 \%$ with good qualifications and according to individual trials the percentage level of eligibility for learning videos is $91,66 \%$ with very good qualifications. Based on the results of the study, it can be concluded that the development of learning videos based on the discovery learning model is feasible to use in the learning process on social studies content for fourth-grade students in elementary schools.

Keywords: Learning Video, Discovery Learning, Social Studies

\section{INTRODUCTION}

Pembelajaran pada abad 21 menekankan pada kemampuan peserta didik dalam berpikir kritis karena melalui berpikir kritis siswa mampu menghubungkan pengetahuannya dengan situasi di dunia nyata. Kecakapan tersebut akan sejalan dengan pembelajaran yang berorientasi terhadap proses. Pembelajaran yang berorientasi terhadap proses relevan dengan kurikulum 2013, dalam penerapannya lebih mengedepankan kompetensi dan karakter (Adittia, 2017; Putrayasa et al., 2014). Adanya kurikulum dengan basis kompetensi dan juga karakter memiliki orientasi untuk mengedepankan proses belajar daripada hasil belajar. Tetapi kenyataanya dewasa ini, banyak sekali permasalahan yang ditemukan seperti rendahya kualitas pendidikan yang mestinya sudah mengedepankan kecakapan abad 21 . Ini berkaitan

$\begin{array}{lll}\text { History: } & & \text { Publisher: Undiksha Press } \\ \text { Received } & \text { : February 15, 2021 } & \text { Licensed: This work is licensed under } \\ \text { Revised } & \text { : March 12, 2021 } & \text { a Creative Commons Attribution 3.0 License } \\ \text { Accepted } & \text { : April 26, 2021 } & \text { Ca (C) (O) } \\ \text { Published } & \text { : May 25, 2021 } & \end{array}$


dengan peran guru dalam merencanakan pembelajaran yang perlu memperhatikan segala komponen pembelajaran dengan baik.

Pada situasi pandemi covid-19, pembelajaran di sekolah khususnya pada jenjang sekolah dasar yang berorientasi terhadap proses memiliki banyak sekali hambatan. Berdasarkan hasil observasi penulis, saat melaksanakan PPL di SD No. 4 Sibangkaja Kecamatan Abiansemal Kabupaten Badung ditemukan bahwa, dalam kegiatan pembelajaran di SD No. 4 Sibangkaja siswa cenderung merasa bosan ketika ada pembelajaran yang banyak menghafal seperti pada muatan IPS. Ini dibuktikan dari rendahnya prestasi belajar serta partisipasi siswa dalam kegiatan pembelajaran daring. Rendahnya prestasi belajar siswa pada muatan IPS diakibatkan karena pembelajaran IPS yang seharusnya dikembangkan untuk memecahkan permasalahan terkait lingkungan sosial di sekitar siswa tidak diterapkan dalam pembelajaran. Selain itu pembelajaran yang berpusat pada guru yang membuat siswa tidak aktif untuk mendapatkan informasi terkait materi palajaran. Guru juga belum mampu menggunakan media pembelajaran yang inovatif dan kreatif yang dapat membuat minat siswa meningkat dalam proses pembelajaran.

Rendahnya minat siswa dalam proses pembelajaran juga diakibatkan oleh kurangnya media dan model pembelajaran untuk memotivasi, merangsang dan menarik perhatian siswa (Kurniawan, 2016; Putri et al., 2016). Siswa sekolah dasar umumya menyukai hal-hal yang konkret dan menyenangkan seperti yang berkaitan dengan kehidupan sehari-hari. Dalam hal ini guru sangat memerlukan media pembelajaran berbasis model pembelajaran yang tepat. Permasalahan di sekolah tersebut jika dibiarkan akan berdampak buruk pada proses pembelajaran. Sebagai upaya untuk menghadapi permasalahan berupa kurangnya motivasi belajar siswa, maka diperlukan media yang mampu meningkatkan motivasi belajar siswa. Salah satu media yang dapat meningkatkan motivasi beralajr ialah media berupa video pembelajaran.

Video pembelajaran efektif dalam meningkatkan prestasi belajar IPS siswa kelas IV sekolah dasar (Muhibuddin Fadhli, 2015; Suryansah \& Suwarjo, 2016). adanya video pembelajaran yang mampu menayangkan unsur audio dan unsur visual, mampu menghilangkan verbalisme yang bersifat kata-kata. Media video pembelajaran sangat cocok diterapkan pada kurikulum 2013 karena memungkinkan siswa untuk aktif mengamati (Agustiningsih, 2015; Wisada et al., 2019). Kelebihan media video pembelajaran yaitu mampu memancing motivasi siswa karena selain melibatkan indra penglihatan dan pendengaran, juga mampu memperlihatkan tindakan nyata yang dituangkan dalam bentuk konkret.

Peran video dalam memotivasi siswa pada saat pembelajaran perlu dimaksimalkan dengan model pembelajaran yang menyenangkan dan menantang. Guru harus memiliki keterampilan dalam memilih model pembelajaran yang seharusnya mampu membangkitkan minat siswa agar lebih aktif, dan kreatif (Listyaningsih, 2017; Pertiwi, 2018). Dalam hal ini landasan yang perlu dipegang guru adalah inovasi untuk membuat siswa lebih aktif, mampu menemukan sendiri pengetahuannya dan dilibatkan dalam proses menggali informasi, serta memecahkan suatu permasalahan. Salah satu model pembelajaran yang mampu membangkitkan minat siswa belajar adalah model pembelajaran discovery learning.

Model pembelajaran discovery learning dipilih sebagai inovasi dalam pengembangan video pembelajaran, berdasarkan pada keunggulannya yang mampu meningkatkan keaktifan peserta didik dalam belajar. Model pembelajaran discovery learning mampu mengarahkan peserta didik untuk aktif menemukan pengetahuan baru yang didapatkan berdasarkan pada pembelajaran sebelumnya (Istikomah, 2018; Salmina, 2019). Melalui pembelajaran discovery learning siswa akan terlibat aktif secara langsung untuk mencari tahu dan memecahkan suatu permasalahan, dengan begitu secara tidak langsung peserta didik telah mengembangkan kemampuan berpikir kritisnya. Belum banyak kajian mengenai pengembangan media video 
pembelajaran berbasis model discovery learning pada pembelajaran di sekolah dasar. Pengembangan video pembelajaran berbasis model discovery learning ini penting dilakukan mengingat dewasa ini sangat diperlukan media pembelajaran berbasis model pembelajaran yang inovatif sebagai sarana menciptakan pembelajaran yang menyenangkan dalam situasi pembelajaran daring.

Beberapa penelitian relevan dengan penelitian ini, seperti penelitian yang dilakukan oleh (Tamba, 2020) yang menyatakan bahwa video pembelajaran berbasis discovery learning layak untuk digunakan terlebih pada sintaks stimulations sangat berpengaruh dan efektif terhadap pemahaman siswa serta dapat meningkatkan kemampuan siswa dalam berpikir kritis. Penelitian lain juga dilakukan dan menemukan bahwa validitas video ini berdasarkan uji ahli (uji ahli isi, media, dan desain pembelajaran) serta uji coba produk (uji peorangan, kelompok kecil, dan lapangan), yaitu sudah sangat baik dan mampu meningkatkan kemampuan siswa kelas XB jurusan akuntasi keuangan lembaga di SMK (Wisada et al., 2019). Penelitian lain menemukan bahwa video pembelajaran menggunakan model problem solving berbantu wondershare valid (layak menurut ahli) dan pembelajaran dengan video pembelajaran menggunakan model problem solving berbantu wondershare lebih efektif dari pada pembelajaran konvensional (Suriyani, 2017). Tujuan penelitian ini untuk menghasilkan produk berupa video pembelajaran berbasis discovery learning yang layak digunakan.

\section{MATERIALS AND METHODS}

Jenis penelitian ini merupakan penelitian pengembangan dengan menggunakan model ADDIE (Analysis, Design, Development, Implementation, Evaluations). Model ADDIE ini dipilih karena alur pengembangannya yang dirasa cocok dalam mengembangkan media video pembelajaran berbasis model discovery learning. Model ADDIE meliputi lima tahap yaitu analisis (analyze), perancangan (design), pengembangan (development), implementasi (implementation), dan evaluasi (evaluation) (Wisada et al., 2019). Metode pengumpulan data yang digunakan dalam penelitian ini adalah metode wanawancara dan kuesioner. Tabel kisikisi instrument ahli isi pembelajaran dapat dilihat pada Tabel 1, kisi-kisi instrumen ahli desain pembelajaran dapat dilihat pada Tabel 2, kisi-kisi instrumen ahli media pembelajaran dapat dilihat pada Tabel 3, kisi-kisi instrumen uji coba perorangan dapat dilihat pada Tabel 4 ,

Tabel 1. Kisi-Kisi Instrumen Ahli Isi Pembelajaran

\begin{tabular}{|c|c|c|c|c|}
\hline No & Aspek & & Indikator & No Butir Jumlah Butir \\
\hline \multirow{3}{*}{1} & \multirow{3}{*}{ Kurikulum } & 1) & $\begin{array}{l}\text { Kesesuaian materi dengan kompetensi } \\
\text { dasar }\end{array}$ & 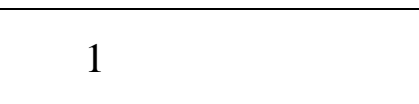 \\
\hline & & 2) & $\begin{array}{l}\text { Kesesuaian materi dengan indikator } \\
\text { pembelajaran }\end{array}$ & 2 \\
\hline & & 3) & $\begin{array}{l}\text { Kesesuaian materi dengan tujuan } \\
\text { pembelajaran }\end{array}$ & 3 \\
\hline \multirow{7}{*}{2} & \multirow{7}{*}{ Materi } & 4) & Kebenaran materi & 4 \\
\hline & & 5) & Materi disajikan secara sistematis & 5 \\
\hline & & $6)$ & Kesesuaian materi dengan situasi siswa & 6 \\
\hline & & 7) & Materi memuat konsep-konsep penting & 7 \\
\hline & & 8) & Materi didukung dengan media yang tepat & 8 \\
\hline & & 9) & $\begin{array}{l}\text { Percobaan dalam video sesuai dengan } \\
\text { konsep materi }\end{array}$ & 9 \\
\hline & & 10) & Soal-soal yang disajikan melatih siswa & 10 \\
\hline
\end{tabular}




\begin{tabular}{|c|c|c|c|c|}
\hline No & Aspek & & Indikator & No Butir Jumlah Butir \\
\hline \multirow{3}{*}{3} & \multirow{3}{*}{ Tata Bahasa } & & berpikir tingkat tinggi & \multirow[t]{3}{*}{ 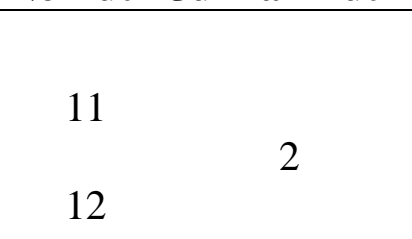 } \\
\hline & & 11) & $\begin{array}{l}\text { Penggunaan Bahasa yang Tepat dan } \\
\text { Konsisten }\end{array}$ & \\
\hline & & 12) & $\begin{array}{l}\text { Bahasa yang digunakan sesuai dengan } \\
\text { karakteristik siswa }\end{array}$ & \\
\hline & & & Jumlah & 12 \\
\hline
\end{tabular}

Tabel 2. Kisi-Kisi Instrumen Ahli Desain Pembelajaran

\begin{tabular}{|c|c|c|c|c|}
\hline No & Aspek & Indikator & No Butir & Jumlah Butir \\
\hline \multirow{4}{*}{1} & \multirow{4}{*}{ Ketepatan } & $\begin{array}{l}\text { 1) Kesesuaian video dengan } \\
\text { karakteristik siswa }\end{array}$ & 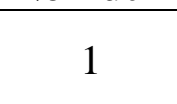 & \multirow{4}{*}{4} \\
\hline & & $\begin{array}{l}\text { 2) Kesesuaian materi dengan tujuan } \\
\text { pembelajaran }\end{array}$ & 2 & \\
\hline & & $\begin{array}{l}\text { 3) Materi dalam video pembelajaran } \\
\text { dikemas secara runtut }\end{array}$ & 3 & \\
\hline & & $\begin{array}{l}\text { 4) Tujuan pembelajaran sesuai } \\
\text { dengan format ABCD }\end{array}$ & 4 & \\
\hline \multirow{4}{*}{2} & \multirow{3}{*}{ Kejelasan } & $\begin{array}{l}\text { 5) Bahasa yang digunakan mudah } \\
\text { dipahami }\end{array}$ & 3 & \multirow{3}{*}{3} \\
\hline & & Kejelasan uraian dan pembahasan & 4 & \\
\hline & & 7) Kejelasan konten yang disediakan & 5 & \\
\hline & \multirow[b]{2}{*}{ Minat } & 8) Video memotivasi siswa belajar & 8 & \multirow[b]{2}{*}{2} \\
\hline 3 & & $\begin{array}{l}\text { 9) Meningkatkan perhatian siswa } \\
\text { dalam proses pembelajaran }\end{array}$ & 9 & \\
\hline 4 & $\begin{array}{l}\text { Kualitas tes dan } \\
\text { penilaiannya }\end{array}$ & $\begin{array}{l}\text { 10) Konsitensi evaluasi dengan tujuan } \\
\text { pembelajaran }\end{array}$ & 10 & 1 \\
\hline 5 & $\begin{array}{l}\text { Dampaknya } \\
\text { bagi siswa }\end{array}$ & $\begin{array}{l}\text { 11) Memudahkan pemahaman siswa } \\
\text { terhadap materi }\end{array}$ & 11 & 1 \\
\hline \multirow[t]{2}{*}{6} & Desain Pesan & 12) Warna gambar nyaman dipandang & 12 & 2 \\
\hline & & $\begin{array}{l}\text { 13) Ketepatan ilustrasi pada deskripsi } \\
\text { Jumlah }\end{array}$ & 13 & 13 \\
\hline
\end{tabular}

Sumber: (Supriatna \& Mulyadi, 2009)

Tabel 3. Kisi-Kisi Instrumen Ahli Media Pembelajaran

\begin{tabular}{|c|c|c|c|c|}
\hline No & Aspek & Indikator & No Butir & Jumlah Butir \\
\hline \multirow{10}{*}{1} & \multirow{10}{*}{ Tampilan } & 1) Keterbacaan teks & 1 & \multirow{10}{*}{14} \\
\hline & & $\begin{array}{l}\text { 2) Penggunaan gambar mendukung materi } \\
\text { pembelajaran }\end{array}$ & 2 & \\
\hline & & 3) Penggunaan jenis huruf dan ukuran huruf & 3 & \\
\hline & & 4) Penempatan gambar yang tepat & 4 & \\
\hline & & 5) Penggunaan jarak baris dan karakter & 5 & \\
\hline & & 6) Komposisi yang digunakan dalam video & 6 & \\
\hline & & $\begin{array}{l}\text { 7) Pemilihan warna dengan kombinasi yang } \\
\text { tepat }\end{array}$ & 7 & \\
\hline & & 8) Ketepatan musik latar & 8 & \\
\hline & & 9) Penggunaan narasi yang sesuai & 9 & \\
\hline & & $\begin{array}{l}\text { 10) Kemenarikan cover CD untuk mengemas } \\
\text { video }\end{array}$ & 12 & \\
\hline
\end{tabular}




\begin{tabular}{|c|c|c|c|c|}
\hline No & Aspek & Indikator & No Butir & Jumlah Butir \\
\hline \multirow{6}{*}{2} & \multirow{6}{*}{$\begin{array}{l}\text { Pengoperas } \\
\quad \text { ian }\end{array}$} & $\begin{array}{l}\text { 11) Kesesuaian cover CD terhadap isi atau } \\
\text { konten }\end{array}$ & 15 & \multirow[t]{6}{*}{ 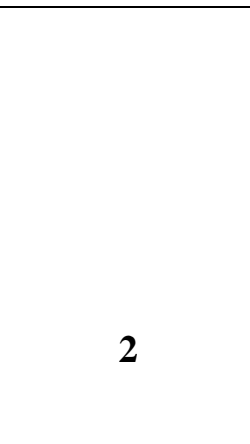 } \\
\hline & & 12) Kejelasan suara presenter dalam video & 13 & \\
\hline & & 13) Kesesuaian video dengan isi & 16 & \\
\hline & & 14) Kejelasan suara narator dalam video & 14 & \\
\hline & & $\begin{array}{l}\text { 1) Media dapat membangkitkan motivasi } \\
\text { siswa dalam belajar }\end{array}$ & 10 & \\
\hline & & $\begin{array}{l}\text { siswa dalam belajar } \\
\text { 2) Durasi waktu video yang efektif untuk } \\
\text { belajar siswa }\end{array}$ & 11 & \\
\hline & & Jumlah & & 16 \\
\hline
\end{tabular}

Tabel 4. Kisi-Kisi Instrumen Uji Coba Perorangan

\begin{tabular}{|c|c|c|c|c|}
\hline No & Aspek & Indikator & No Butir & Jumlah Butir \\
\hline \multirow[t]{4}{*}{1} & \multirow{4}{*}{ Desain Pesan } & a) Kemenarikan pembukaan video & 1 & \multirow{4}{*}{5} \\
\hline & & b) Keterbacaan teks & 2 & \\
\hline & & c) Kejelasan gambar & 3 & \\
\hline & & d) Kejelasan suara & 4,5 & \\
\hline \multirow[t]{2}{*}{2} & \multirow{2}{*}{ Materi } & e) Kemudahan pemahaman materi & 6,7 & \multirow{2}{*}{4} \\
\hline & & f) Kejelasan uraian materi & 8,9 & \\
\hline \multirow[t]{2}{*}{3} & Motivasi & $\begin{array}{l}\text { g) Media memberikan semangat } \\
\text { siswa dalam belajar }\end{array}$ & 10 & 1 \\
\hline & \multicolumn{3}{|c|}{ Jumlah } & 10 \\
\hline
\end{tabular}

Pada penelitian ini metode yang digunakan untuk analisis data adalah metode analisis deskriptif kuantitatif dan analisis deskriptif kualitatif. Dalam penelitian ini, analisis deskriptif kuantitatif dipergunakan sebagai pengolahan data yang diperoleh melalui angket diubah dalam bentuk skor sehingga menjadi persentase respon dari subjek yang diteliti. Untuk pengambilan makna dan pengambilan keputasan mengenai pengembangan video pembelajaran maka digunakan konversi tingkat pencapaian dengan skala 5. Konversi tingkat pencapaian dengan skala 5 dapat dilihat pada Tabel 5. Metode analisis data deskriptif kualitatif digunakan untuk mengolah data hasil uji ahli isi, ahli media, ahli desain dan uji coba perorangan. Data yang dimaksud berupa komentar, masukan atau saran yang terdapat pada kuesioner para ahli maupun siswa.

Tabel 5. Konversi Tingkat Pencapaian dengan Skala 5

\begin{tabular}{cccc}
\hline Tingkat Pencapaian \% & Nilai Angka & Nilai Huruf & Predikat \\
\hline $90-100$ & 4 & $\mathrm{~A}$ & Sangat Baik \\
$80-89$ & 3 & $\mathrm{~B}$ & Baik \\
$65-78$ & 2 & $\mathrm{C}$ & Cukup \\
$40-64$ & 1 & $\mathrm{D}$ & Kurang \\
$00-39$ & 0 & $\mathrm{E}$ & Sangat Kurang \\
\hline
\end{tabular}

\section{RESULTS AND DISCUSSION}

Hasil penelitian ini berupa (1) deskripsi rancang bangun video pembelajaran berbasis model discovery learning, dan (2) deskripsi validitas pengembangan video pembelajaran 
berbasis model discovery learning. Rancang bangun video pembelajaran ini menggunakan model pengembangan ADDIE dengan lima tahapannya, yaitu sebagai berikut.

Tahap pertama, yaitu analisis (analyze). Tahap analisis bertujuan untuk menganalisis konten, menganalisis karakteristik siswa dan menganalisis fasilitas dalam lingkungan sekolah dalam kaitannya dengan kebutuhan yang diperlukan untuk memecahkan masalah penelitian berupa pengembangan produk. Berdasarkan hasil analisis konten dengan metode wawancara dan kuesioner pada wali kelas IV dan siswa kelas IV SD No. 4 Sibangkaja ditemukan bahwa media pembelajaran yang cocok untuk dikembangkan adalah media video pembelajaran.

Tahap kedua, yaitu tahap desain (design). Dalam tahap ini dilakukan perancangan video pembelajaran dengan menggunakan aplikasi yang telah dipilih. Aplikasi pembuatan video yang digunakan dalam penelitian ini adalah Power Point 2019, Canva, dan Kinemaster. Rancangan yang dilakukan dalam tahap desain yaitu perancangan storyboard, naskah video pembelajaran dan RPP pelaksanaan pembelajaran. Storyboard video pembelajaran digunakan untuk merancang tampilan serta penempatan gambar dan tulisan. Naskah video pembelajaran dirancang untuk memudahkan narrator dalam memahami alur dari video pembelajaran yang dikembangkan. Selanjutnya dalam tahap rancangan, dibuatlah desain komponen video pembelajaran seperti; perancangan tulisan, gambar dan background menggunakan aplikasi Power Point 2019, dan Canva.

Tahap ketiga, yaitu tahap pengembangan (development). Pada tahap ini dilakukan pengembangan dari media video pembelajaran agar siap digunakan untuk proses pembelajaran. Setiap rancangan tampilan video yang telah dibuat pada tahap desain akan diproses menjadi video dengan aplikasi pembuat video yaitu Kinemaster Pro. Dalam tahap ini dilakukan juga penambahan musik, efek dan juga finishing agar video pembelajaran menarik untuk dilihat.

Tahap keempat, yaitu tahap implemantasi (implementation). Pada tahapan implementasi media video pembelajaran, dilakukan untuk mengetahui tingkat kelayakan video pemebelajaran berdasarkan para ahli dan respon siswa terkait kemenarikan serta kelayakan media video pembelajaran. Tahapan dalam implementasi dimulai dari uji validitas oleh ahli isi, uji validitas oleh ahli media pembelajaran, dan uji validitas oleh ahli desain pembelajaran. Setelah melakukan uji ahli dan revisi produk maka dilakukan uji coba perorangan kepada siswa kelas IV sekolah dasar sebanyak tiga orang dengan masing-masing siswa berkemampuan tinggi, sedang dan rendah. Pada tahapan ini metode yang digunakan untuk menyaring data tingkat kelayakan video pembelajaran adalah metode kuesioner.

Tahap kelima, yaitu tahap evaluasi (evaluation). Pada tahap ini dilakukan evaluasi video pembelajaran berbasis model discovery learning. Evaluasi yang dilakuakan dalam penelitian ini adalah evaluasi formatif, yang dilakukan sebagai upaya revisi dan penyempurnaan produk berdasarkan hasil revisi dari para ahli meliputi; ahli materi pelajaran, ahli desain pembelajaran, ahli media pembelajaran dan siswa dalam uji coba perorangan.

Berdasarkan dari setiap tahapan yang telah dilaksanakan, didapatkan hasil validitas video pembelajaran berdasakarkan para ahli dan uji coba perorangan. Hasil uji validitas pengembangan video pembelajaran berbasis model discovery learning dapat dilihat pada Tabel 6.

Tabel 6. Hasil Uji Validitas Produk

\begin{tabular}{clcc}
\hline No & \multicolumn{1}{c}{ Subjek Uji Coba } & Hasil Validitas & Kualifikasi Persentase \\
\hline 1 & Uji Ahli Isi Mata Pelajaran & $93.75 \%$ & Sangat Baik \\
\hline 2 & Uji Ahli Desain Pembelajaran & $90.38 \%$ & Sangat Baik \\
3 & Uji Ahli Media Pembelajaran & $87.5 \%$ & Baik \\
4 & Uji Coba Perorangan & $91.66 \%$ & Sangat Baik \\
\hline
\end{tabular}


Berdasarkan Tabel 6, persentase hasil dari validitas pengembangan video pembelajaran menurut para ahli dan subjek uji coba, jika diurutkan sebesar 93.75\%, 90.38\%, $87.5 \%, 91.66 \%$. Sebagian besar dari kualifikasi video pembelajaran ini berkualifikasi sangat baik sehingga layak digunakan dalam kegiatan pembelajaran di dalam kelas.

Produk yang dihasilkan dalam penelitian ini berupa video pembelajaran berbasis model discovery learning untuk kelas IV SD No. 4 Sibangkaja. Video pembelajaran ini dirancang untuk membantu siswa berpikir kritis dan bereksplorasi demi mendapatkan proses pembelajaran yang menyenangkan. Video pembelajaran yang dikembangkan memuat materi pelajaran IPS mengenai Sumber Daya Alam. Video pembelajaran ini disertai dengan gambargambar yang mendukung sehingga membantu siswa dalam memahami materi pelajaran. Untuk mengembangkan video pembelajaran ini maka digunakan model pengembangan ADDIE. Model ADDIE dipilih karena tahapannya yang bersifat sistematik dan sesuai dengan alur pengembangan video pembelajaran. Model ADDIE dikembangkan dengan sistematis berdasarkan kepada desain pembelajaran yang sesuai sehingga dapat memecahkan permasalahan terkait sumber belajar yang sesuai dengan karakteristik siswa (Agustien et al., 2018; Tegeh \& Kirna, 2013). Selain itu penelitian yang pernah dilakukan oleh (Angko, 2013) yang menyatakan bahwa tingkat feksibilitas model ADDIE mampu menjawab permasalahan dengan fleksibilitas yang cukup tinggi dan relevan sampai saat ini.

Model ADDIE mampu memberikan tahapan pengembangan produk yang sesuai dengan karakteristik siswa (Tegeh \& Kirna, 2013), ini didasarkan dari tahapan analisis pada model ADDIE. Analisis diperlukan untuk mengetahui materi pelajaran yang memerlukan media pembelajaran inovatif berdasarkan ketersediaan fasilitas dan kurangnya media pembelajaran yang sesuai karakteristik siswa. Analisis karakteristik belajar siswa, mampu mengetahui gaya belajar yang tepat untuk siswa (Ponza et al., 2018; Sari, 2014). Pembuatan media harus mempertimbangkan fungsi edukatif (Asyhari, 2016). Fungsi edukatif berarti harus ada kesesuaian antara gaya belajar siswa, karakteristik siswa dan kebutuhan siswa dalam pembuatan media pembelajaran. Berdasarkan fungsi edukatif media pembelajaran yang dikembangkan adalah video pembelajaran berbasis discovery learning. Discovery Learning dijadikan dasar pada media video pembelajaran ini berdasarkan penelitian yang dilakukan (Setyawati, 2019; Yuliana, 2019) yang menyatakan bahwa dengan menerapkan model discovery learning maka akan meningkatkan kemampuan peserta didik dalam berpikir kritis sehingga kondisi belajar yang semula pasif menjadi lebih aktif dan kreatif. Ini dikarenakan peserta didik terlibat aktif dalam menemukan pengetahuannya yang menjadikan peserta didik lebih memahami materi pelajaran.

Tahap selanjutnya pada model ADDIE yaitu desain. Tahap desain memiliki tujuan agar video pembelajaran mampu memenuhi fungsi estetik yang sesuai dengan syarat pembuatan media. Video pembelajaran harus memberikan warna, komposisi dan suara yang memiliki daya tarik dan seni yang tinggi sehingga menarik perhatian siswa. Selain itu media juga harus dirancang agar mudah dilihat, menarik, sederhana, dan tersusun dengan baik (Asyhari, 2016; Nurseto, 2012). Untuk lebih menyempurnakan media pembelajaran maka tahap selanjutnya adalah tahap pengembangan produk. Pengembangan produk menyesuaikan dengan tahapan desain yang mengutamakan pada keindahan dan keserasian video pembelajaran sebelum siap dilanjutkan pada tahapan implementasi.

Validitas pengembangan video pembelajaran ini diperolah pada saat implementasi yang dilakukan oleh para ahli dan siswa. Data yang didapatkan melalui angket kemudian diolah ke dalam bentuk skor persentase dan dikonversikan sehingga diketahui tingkat kelayakannya. Hasil validitas uji mata pelajaran dalam pengembangan video ini menunjukkan bahwa tingkat persentase kualitas video berkualifikasi sangat baik dan layak untuk diteruskan. Keunggulan video pemebelajaran ini dari aspek materi pelejaran dikarenakan kesesuaian materi yang ada pada video pembelajaran dengan situasi di dunia 
nyata. Pembelajaran IPS masih dipandang pembelajaran yang membosankan karena kurangnya keterkaitan situasi di dunia nyata yang dapat dilihat siswa dan dapat dikembangkan untuk memecahkan permasalahan di dunia nyata terkait interaksi terhadap manusia maupun lingkungan (Ariani et al., 2020; Muhibuddin Fadhli, 2015). Dengan begitu dari aspek materi pelajaran, video pembelajaran berbasis discovery learning sangat layak digunakan untuk siswa kelas IV sekolah dasar.

Aspek selanjutnya yaitu hasil validasi ahli desain pembelajaran yang menunjukkan skor persentase dengan kualifikasi sangat baik sehingga sangat layak untuk diteruskan. Keunggulan video pembelajaran berbasis discovery learning ini dikarenakan adanya kesesuaian desain pembelajaran dengan karakteristik siswa. Ini didasarkan pada tahapan model ADDIE pada tahap analisis telah melakukan analisis kebutuhan dan telah menggunakan prinsip edukatif. Terlebih media sebagai sumber belajar harus mampu menampung materi pelajaran yang nantinya memudahkan peserta didik dalam memperoleh pemahaman yang lebih konkret. Selain itu video pembelajaran ini juga mampu meningkatkan motivasi siswa berdasarkan penilaian dari ahli desain pembelajaran. Kelebihan video pemebelajaran yang mampu meningkatkan motivasi siswa, sesuai dengan fungsi media pembelajaran. Fungsi motivasi dimana media pembelajaran diharapkan mampu meningkatkan motivasi belajar siswa (Aghni, 2018). video pembelajaran memang membawa dampak positif bagi kegiatan pembelajaran peserta didik khususnya dalam meningkatkan motivasi mereka (Agustini, 2020; Risabethe, 2016). Sebagai media yang menarik, video merupakan salah satu solusi untuk guru dari permasalahan berupa rendahnya motivasi belajar peserta didik.

Hasil validitas pengembangan video berdasarkan uji validitas ahli media pembelajaran mencapai tingkat persentase dengan kualifikasi baik dan layak diteruskan. Kelebihan video pembelajaran ini dari aspek media pembelajaran karena warna dan kombinasi pada media yang tepat selain itu kejelasan suara, dan tulisan yang mendukung kemenarikan video pembelajaran dari aspek media. Adanya musik dan suara narrator yang jelas mampu menarik perhatian siswa (Wisada et al., 2019). Seperti yang dibuktikan pada uji coba perorangan pada tiga orang siswa kelas empat sekolah dasar menunjukkan bahwa dari aspek komposisi warna, kejelasan suara dan kejelasan teks menunjukkan perolehan yang tinggi sehingga skor persentase keseluruhan dengan kualifikasi sangat baik dan layak untuk diteruskan. Berdasarkan atas kualifikasi keseluruahan media pembelajaran maka video pembelajaran berbasis discovery learning layak untuk digunakan dalam kegiatan pembelajaran di dalam kelas. Pengembangan video pembelajaran berbasis model discovery learning ini tidak sampai kepada uji efektifitas produk karena keterbatasan penelitian.

\section{CONCLUSION}

Video pembelajaran berbasis model discovery learning sangat layak digunakan dalam kegiatan pembelajaran untuk siswa kelas IV sekolah dasar dalam memotivasi serta meningkatkan pemahaman siswa terhadap materi pelajaran. Kelayakan video pembelajaran ini didasari dari penilaian video pembelajaran dari aspek isi, desain pembelajaran dan media pembelajaran, dengan kualifikasi sangat baik sehingga video pembelajaran ini dapat digunakan dalam proses pembelajaran pada situasi pembelajaran daring.

\section{REFERENCES}

Adittia, A. (2017). Penggunaan Media Pembelajaran Audio Visual untuk Meningkatkan Hasil Belajar IPS Pada Siswa Kelas IV SD. Mimbar Sekolah Dasar, 4(1), 9-20. https://doi.org/10.23819/mimbar-sd.v4i1.5227. 
Aghni, R. I. (2018). Fungsi dan Jenis Media Pembelajaran dalam Pembelajaran Akuntansi. $X V I(1)$.

Agustien, R., Umamah, N., \& Sumarno, S. (2018). Pengembangan Media Pembelajaran Video Animasi Dua Dimensi Situs Pekauman di Bondowoso Dengan Model Addie Mata Pelajaran Sejarah Kelas X IPS. Jurnal Edukasi, 5(1), 19. https://doi.org/10.19184/jukasi.v5i1.8010.

Agustini, K. (2020). Pengembangan Video Pembelajaran Untuk Meningkatkan Motivasi Belajar Siswa Menggunakan Model $R \&$ \& D. 4 (April 2020), 62-78.

Agustiningsih, A. (2015). Video Sebagai Alternatif Media Pembelajaran Dalam Rangka Mendukung Keberhasilan Penerapan Kurikulum 2013 di Sekolah Dasar. Pedagogia: Jurnal Pendidikan, 4(1), 50. https://doi.org/10.21070/pedagogia.v4i1.72.

Angko, N. and M. (2013). Pretest Posttest Group . Kwangsan, 1(1), 1-15.

Ariani, K. R., Sumantri, M., \& Parmiti, D. P. (2020). Pengembangan Video Pembelajaran IPS Bermuatan Tes untuk Siswa. Jurnal Ilmiah Pendidikan Profesi Guru, 3(2), 217. https://doi.org/10.23887/jippg.v3i2.28260.

Asyhari, A. (2016). Pengembangan Media Pembelajaran Berupa Buletin Dalam Bentuk Saku Untuk Pembelajaran IPA Terpadu. Jurnal Ilmiah Pendidikan Fisika, 5, 1-13. https://doi.org/10.24042/jpifabiruni.v5i1.100.

Istikomah, N. (2018). Penerapan Model Discovery Learning Pada Pembelajaran Ips Untuk Meningkatkan Keaktifan Dan Hasil Belajar Kognitif Siswa Sekolah Dasar. Jurnal Didaktika Dwija Indria (SOLO), 6(3), 130-139.

Kurniawan, T. D. (2016). Pengaruh Penggunaan Media Video Pembelajaran Terhadap Prestasi Belajar Ilmu Pengetahuan Sosial Siswa Kelas V SD Se-Kecamatan Gedangsari Gunungkidul Tahun Ajaran 2015/2016. Trihayu: Jurnal Pendidikan Ke$S D-A n, 3(1), 21-26$.

Listyaningsih, S. (2017). Peningkatan Hasil Belajar Melalui Penerapan Model Pembelajaran Kooperatif Numbered Head Together.

Muhibuddin Fadhli. (2015). Pengembangan Media Pembelajaran Berbasis Video Kelas IV Sekolah Dasar. Jurnal Pendidikan, 3. https://doi.org/10.24269/dpp.v3i1.157.

Nurseto, T. (2012). Membuat Media Pembelajaran yang Menarik. Jurnal Ekonomi Dan Pendidikan, 8(1), 19-35. https://doi.org/10.21831/jep.v8i1.706.

Ponza, P. J. R., Jampel, I. N., \& Sudarma, I. K. (2018). Pengembangan Media Video Animasi pada Pembelajaran Siswa Kelas IV di Sekolah Dasar. Jurnal Edutech Undiksha, 6(1), 9-19. https://doi.org/http://dx.doi.org/10.23887/jeu.v6i1.20257.

Putrayasa, I. M., Syahruddin, H., \& Mergunayasa, I. G. (2014). Pengaruh Model Pembelajaran Discovery Learning Dan Minat Belajar Terhadap Hasil Belajar IPA Siswa. Jurnal Mimbar PGSD Universitas Pendidikan Ganesha, 2(1), 1-11.

Putri, W. M., Bakri, F., \& Permana, A. H. (2016). Pengembangan Media Pembelajaran Berbasis Multimedia Augmented Reality. V, 83-88.

Salmina, M. M. (2019). Penerapan Model Pembelajaran Discovery Learning Pada Materi Dimensi Tiga Dengan Bantuan Video Pembelajaran. 6(2), 247-254.

Sari, A. K. (2014). Analisis Karakteristik Gaya Belajar Vak(Visual, Auditorial, Kinestetik)Mahasiswa Pendidikan Informatika Angkatan 2014. Edutic - Scientific Journal of Informatics Education, 1(1), 1-12. https://doi.org/10.21107/edutic.v1i1.395.

Supriatna, S., \& Mulyadi, M. (2009). Konsep Dasar Desain Pembelajaran. Pusat Pengembangan dan Pemberdayaan Pendidik dan Tenaga Kependidikan.

Suriyani, I. (2017). Pengembangan Video Pembelajaran Menggunakan Model Problem Solving Berbantu Wondershare Pada Materi Statistika di SMP. Aksioma, 7(1), 1. https://doi.org/10.26877/aks.v7i1.1405. 
Suryansah, T., \& Suwarjo, S. (2016). Pengembangan Video Pembelajaran Untuk Meningkatkan Motivasi Dan Hasil Belajar Kognitif Siswa Kelas IV SD. Jurnal Prima Edukasia, 4(2), 209. https://doi.org/10.21831/jpe.v4i2.8393.

Tamba, R. (2020). Pengembangan Media Video Berbasis Model Pembelajaran Discovery Learning Pada Materi Gerak Lurus. Journal of Chemical Information and Modeling, $21(1), 1-9$.

Tegeh, I. M., \& Kirna, I. M. (2010). Metode Penelitian Pengembangan Pendidikan. Universitas Pendidikan Ganesha.

Tegeh, I. M., \& Kirna, I. M. (2013). Pengembangan Bahan Ajar Metode Penelitian Pendidikan dengan ADDIE Model. Jurnal Pendidikan, 11(1), 16.

Wisada, P. D., Sudarma, I. K., \& Yuda S, A. I. W. I. (2019). Pengembangan Media Video Pembelajaran Berorientasi Pendidikan Karakter. Journal of Education Technology, 3(3), 140. https://doi.org/10.23887/jet.v3i3.21735.

Yuliana, N. (2019). Penggunaan Model Pembelajaran Discovery Learning Dalam Peningkatan Hasil Belajaran Siswa Di Sekolah Dasar. Pedagogi: Jurnal Ilmu Pendidikan, 18(2), 56. https://doi.org/10.24036/fip.100.v18i2.318.000-000. 